\title{
Pengaruh Kecerdasan Emosional Siswa Terhadap Akhlak Siswa Kepada Teman di Mts. MAI Purwakarta
}

\author{
Munawar Sanusi \\ STAI DR. KHEZ. Muttaqien Purwakarta, Indonesia \\ munawar.sanusi@gmail.com \\ Ummu Salamah \\ MTs MA MAI Purwakarta, Indonesia \\ u.salamah@gmail.com
}

DOI: https://doi.org/10.52593/pdg.01.1.04

Naskah diterima: 27 Maret 2020, direvisi: 30 April 2020, disetujui: 21 Juni 2020

\begin{abstract}
Abstraksi
Penelitian ini bertujuan untuk mengetahui kecerdasan emosional siswa, akhlak siswa kepada teman dan sejauhmana pengaruh kecerdasan emosional siswa terhadap akhlak siswa kepada teman di kelas VIII E MTs. MAI Purwakarta. Pendekatan kuantitatif dengan metode studi korelasional adalah metode yang digunakan dalam penelitian ini. Jenis data dikelompokkan menjadi dua kategori, primer dan sekunder. Teknik pengumpulan data dilakukan dengan cara observasi, dan angket. Analisis data yang digunakan adalah data kuantitatif dengan cara menganalisis data yang tersedia, serta menarik kesimpulan. Teori tentang kecerdasan emosional menghasilkan indikator kemampuan siswa untuk mengenali emosi diri, mengelola emosi diri, memotivasi diri sendiri, mengenali emosi orang lain (empati) dan kemampuan untuk membina hubungan (kerjasama) dengan orang lain.dan teori akhlak merupakan variabel independent yang mempengaruhi baik dan buruknya akhlak seseorang adalah memiliki kecerdasan emosional yang baik. Hasil penelitian dari data yang telah dianalisis dapat ditarik kesimpulan bahwa rata-rata kecerdasan emosional siswa baik. Hasil perhitungan terhadap data sampel diperoleh nilai kecerdasan emosional siswa $=76,13 \%$. Rata-rata akhlak siswa kepada teman baik. Hasil perhitungan terhadap data sampel diperoleh nilai akhlak siswa kepada teman $=75,49 \%$. Pengaruh kecerdasan emosional siswa berpengaruh terhadap akhlak siswa kepada teman, meskipun nilai pengaruhnya hanya $37,80 \%$ dan memiliki nilai korelasi 0,615 yang dapat dikategorikan bahwa pengaruh antara kedua variabel kuat. Sehingga kecerdasan emosional siswa perpengaruh secara nyata dan positif terhadap akhlak siswa kepada teman sebesar $37,80 \%$, dan sisanya $62,20 \%$ dipengaruhi oleh variabel lain di luar penelitian.
\end{abstract}

Kata Kunci : Kecerdasan, Emosi, Akhlak, Teman

\section{A. Pendahuluan}

Pendidikan adalah investasi jangka panjang yang memerlukan usaha dan dana yang cukup besar, hal ini diakui oleh semua orang atau suatu bangsa demi kelangsungan masa depannya. Demikian halnya dengan Indonesia menaruh harapan besar terhadap pendidik dalam perkembangan masa depan bangsa ini, karena dari sanalah tunas muda harapan bangsa sebagai generasi penerus dibentuk. Melalui pendidikan seseorang tidak hanya pandai secara keilmuan, tetapi juga memiliki budi pekerti dan perilaku yang baik.

Sekolah merupakan tempat bagaimana anak belajar berinteraksi dengan orang lain. Sekolah harus membangun budaya yang mengedepankan aspek moral, cinta kasih, kelembutan, nilai demokratis, menghargai perbedaan, berlapang dada menerima kenyataan, dan menjauhkan 
diri dari nilai-nilai kekerasan. Sekolah harus meningkatkan kecerdasan emosional (psikologis) yang berpengaruh terhadap faktor Akhlak (tingkah laku) siswa agar dapat mencapai tingkat mutu pendidikan.

Kedudukan akhlak dalam kehidupan manusia menempati tempat yang penting, sebagai individu, masyarakat dan bangsa. Akhlak merupakan hal yang sangat penting dalam kehidupan beragama, bermasyarat dan berbangsa serta bernegara. Akhlak merupakan proses esensi ajaran islam disamping aqidah dan syariah. Karena dengan akhlak akan terbina mental dan jiwa seseorang untuk memiliki hakekat kemanusiaan yang tinggi.

Mengetahui diri sendiri berarti mengetahui potensi-potensi dan kemampuan yang dimiliki sendiri, mengetahui kelemahan-kelemahan dan juga perasan dan emosi. Dengan mengetahui hal tersebut, seseorang mestinya juga bisa mendayagunakan, mengekspresikan, mengendalikan dan juga mengkomunikasikan dengan pihak lain.

Sekolah merupakan tempat bagaimana anak belajar berinteraksi dengan orang lain. Sekolah harus membangun budaya yang mengedepankan aspek moral, cinta kasih, kelembutan, nilai demokratis, menghargai perbedaan, berlapang dada menerima kenyataan, dan menjauhkan diri dari nilai-nilai kekerasan. Sekolah harus meningkatkan kecerdasan emosional (psikologis) yang berpengaruh terhadap faktor Akhlak (tingkah laku) siswa agar dapat mencapai tingkat mutu pendidikan.

Semua permasalahan di atas merupakan sebuah realita yang mana kecerdasan emosional itu sangat berpengaruh tehadap tingkah laku (akhlak) seseorang. Pengaruh kecerdasan emosional bisa digambarkan melalui kekuatan emosi seseorang yang bisa lebih kuat daripada kekuatan logikanya. Itu karena, otak logika berfikir kalah cepat dengan otak emosi. Yang dimaksud dengan otak emosi, adalah bagian otak yang disebut amigdala, yaitu bagian yang berproses memberikan respon berupa tindakan emosional.

Permasalahan yang banyak terjadi di Madrasah Tsanawiyah MAI Purwakarta adalah permasalahan yang berhubungan rendahnya akhlak siswa, adapun faktor internal yang menyebabkan hal tersebut ialah kurangnya kemampuan siswa dalam mengendalikan emosi serta keadaan pola pikir yang masih labil sehingga mudah terpengaruh oleh untuk melakukan hal yang negatif. Hal tersebut sangat mempengaruhi tingkah laku atau akhlak mereka di sekolah. selain faktor internal, adapula faktor eksternal yang menyebabkan siswa kurang memiliki akhlak yang baik, diantaranya adalah faktor pendidikan dalam keluarga. Anak-anak yang memiliki permasalahan keluarga (broken home) sering mangalami stress yang berlebihan sehingga akan membuat mereka tidak besemangat dalam mengikuti pelajaran, selalu mengeluh, kurangnya motivasi belajar, meluapkan amarah dengan bersikap kurang baik terhadap teman dan guru disekolah, merasa ingin selalu ingin diperhatikan oleh guru, dan sebagainya. Yang akhirnya berdampak pada rendahnya akhlak yang dimiliki oleh siswa.

Berdasarkan uraian diatas, dalam kaitan pentingnya kecerdasan emosional pada diri siswa sebagai salah satu faktor yang sangat berpengaruh dalam pembentukan akhlaknya, penulis merasa tertarik untuk mengadakan penelitian dengan mengangkat judul, "Pengaruh Kecerdasan Emosional terhadap Akhlak Siswa kepada Teman pada Kelas VIII E MTs. MAI Purwakarta".

Hal ini bertitik tolak dari latar belakang masalah yang telah diuraikan di atas dapat diidentifikasi karena masih rendahnya akhlak dan kepribadian baik siswa, masih kurangnya kemampuan siswa dalam mengendalikan emosi, masih rendahnya kesadaran siswa dalam menjalin hubungan yang baik dengan teman sebaya, dan dalam penelitian ini difokuskan pada 
pengaruh kecerdasan emosional terhadap akhlak siswa kepada teman kelas VIII E MTs. MAI Purwakarta.

Adapun rumuskan dan tujuannya adalah sebagai berikut: 1) Bagaimana kecerdasan emosional siswa kelas VIII E MTs. MAI Purwakarta; 2) Bagaimana akhlak siswa kepada teman kelas VIII E MTs. MAI Purwakarta; 3) Bagaimana pengaruh kecerdasan emosional terhadap akhlak siswa kepada teman kelas VIII E MTs. MAI Purwakarta. Dengan harapan dari hasil penelitian diharapkan memberikan kontribusi bagi sekolah, guru, institusi dan peneliti.

\section{B. Teori / Konsep}

\section{Kecerdasan Emosional}

Menurut Daniel Goleman emosi merujuk pada suatu perasaan dan pikiran yang khas, suatu keadaan biologis dan psikologis dan serangkaian kecenderungan untuk bertindak. Emosi pada dasarnya adalah dorongan untuk bertindak. Biasanya emosi merupakan reaksi terhadap rangsangan dari luar dan dalam diri individu. Sebagai contoh emosi gembira mendorong perubahan suasana hati seseorang, sehingga secara fisiologi terlihat tertawa, emosi sedih mendorong seseorang berperilaku menangis.(Manpan Drajat, 2015; Nurpratiwi, 2021)

Kecerdasan emosional, yaitu kecerdasan kalbu yang berkaitan dengan pengendalian nafsu-nafsu implusif dan agresif. Kecerdasan ini mengarahkan seseorang untuk bertindak secara hati-hati, waspada, tenang, sabar dan tabah ketika mendapat musibah, dan berterima kasih ketika mendapat kenikmatan.

Istilah "kecerdasan emosional" pertama kali dilontarkan pada tahun 1990 oleh psikolog Peter Salovey dari Harvard University dan John Mayer dari University of New Hampshire untuk menerangkan kualitas-kualitas emosional yang tampaknya penting bagi keberhasilan.

Kecerdasan emosional sangat dipengaruhi oleh lingkungan, tidak bersifat menetap, dapat berubah-ubah setiap saat. Untuk itu peranan lingkungan terutama orang tua pada masa kanak-kanak sangat mempengaruhi dalam pembentukan kecerdasan emosional. Keterampilan EQ bukanlah lawan keterampilan IQ atau keterampilan kognitif, namun keduanya berinteraksi secara dinamis, baik pada tingkatan konseptual maupun di dunia nyata. Selain itu, EQ tidak begitu dipengaruhi oleh faktor keturunan.

\section{Akhlak Siswa kepada Teman}

Dalam kamus besar bahasa Indonesia kata akhlak diartikan sebagai budi pekerti atau kelakuan. Kata "akhlaq" berasal dari bahasa Arab, yaitu jama' dari kata "khuluqun" yang secara linguistik diartikan dengan budi pekerti, perangai, tingkah laku atau tabiat, tata krama, sopan santun, adab, dan tindakan. Secara terminologis dapat dikatakan bahwa akhlak merupakan pranata perilaku manusia dalam segala aspek kehidupan. Dalam pengertian umum, akhlak dapat dipadankan dengan etika atau nilai moral. 
Imam Al Ghazali dalam Ihya Ulumuddin menyatakan bahwa akhlak ialah daya kekuatan (sifat) yang tertanam dalam jiwa dan pendorong perbuatan-perbuatan spontan tanpa memerlukan pertimbangan pikiran. Jadi, akhlak merupakan sikap yang melekat pada diri seseorang dan secara spontan diwujudkan dalam tingkah laku dan perbuatan.

Akhlak kepada sesama adalah etika yang baik terhadap teman dalam menjaga perkataan dan perilaku. Setiap orang pasti membutuhkan orang lain dalam hidupnya, dalam hal apapun, termasuk dalam pergaulan. Oleh karena itu, dalam kehidupan sehari-hari seseorang membutuhkan teman.

Dengan tiga metode sufistik, yaitu takhalli, tahalli, dan tajalli, dapat dijelaskan secara lebih rinci bahwa akhlak secara umum terdiri atas dua macam, yaitu akhlak terpuji atau akhlak mulia yang disebut dengan al-akhlaq al-mahmudah atau al akhlaq al-karimah, dan akhlak tercela atau akhlak yang dibenci, yakni disebut akhlaq almazmumah.

Akhlak yang terpuji adalah akhlak yang dikehendaki Allah SWT. dan dicaontohkan oleh Rasulullah SAW. Akhlak ini diartikan sebagai akhlak orang-orang yang beriman kepada Allah SWT. Adapun akhlak tercela adalah akhlak yang dibenci oleh Allah SWT. sebagaimana akhlak orang-orang kafir, orang-orang musyrik, dan orang-orang munafik.

Sebaliknya, akhlak orang-orang yang tercela adalah orang-orang yang berperilaku atas nama selain Allah SWT. Orang-orang yang menghambakan diri kepada nafsunya. Orang-orang yang selalu berada di jalan yang bengkok, yaitu jalan menuju neraka, jalan yang nikmatnya sementara, dan jalan yang dibenci Allah SWT.

Menurut Az-Zarnuji, indikator akhlak yang baik terhadap teman dalam Islam diantaranya sebagai berikut: 1) rendah hati dan tidak sombong; 2) saling kasih mengasihi; 3) memberi perhatian terhadap sahabat; 4) selalu membantu keperluan sahabat; 5) menjaga kawan dari gangguan orang lain; 6) memberi nasihat dan kritik; 7) mendamaikan jika berselisih; 8) mendoakan dengan kebaikan.

\section{Kerangka Berfikir dan Paradigma Penelitian}

\begin{tabular}{|c|c|}
\hline $\begin{array}{c}\text { Kecerdasan } \\
\text { Emosional }\end{array}$ & \\
\hline \multirow{6}{*}{$\begin{array}{l}\text { Indikator: } \\
\text { 1. Kesadaran diri } \\
\text { 2. Mengelola emosi } \\
\text { 3. Memanfaatkan emosi } \\
\text { secara efektif } \\
\text { 4. Empati } \\
\text { 5. Membina hubungan }\end{array}$} & \multirow[b]{2}{*}{$S$} \\
\hline & \\
\hline & \\
\hline & I \\
\hline & $\mathrm{S}$ \\
\hline & 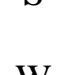 \\
\hline & $\mathrm{W}$ \\
\hline & A \\
\hline & $\uparrow$ \\
\hline
\end{tabular}

\begin{tabular}{|c|}
\hline $\begin{array}{c}\text { Akhlak Siswa } \\
\text { kepada Teman }\end{array}$ \\
\hline
\end{tabular}

Indikator:

1. Rendah hati dan tidak sombong

2. Saling kasih mengasihi

3. Memberi perhatian terhadap keadaan sahabat

4. Selalu membantu keperluan sahabat

5. Menjaga kawan dari gangguan orang lain

6. Memberi nasihat dan kritik

7. Mendamaikan jika berselisih

8. Mendoakan dalam kebaikan 


\section{Hipotesis Penelitian}

Dari penelitian ini penulis dapat mengambil hipotesis sebagai berikut:

a. Kecerdasan emosional siswa lebih dari $60 \%$ dengan kategori cukup

Ha : Kecerdasan emosional siswa lebih dari $60 \%$

Ho : Kecerdasan emosional tidak lebih dari $60 \%$

b. Akhlak siswa kepada teman lebih dari $60 \%$, dengan kategori cukup

Ha : Akhlak siswa kepada teman lebih dari $60 \%$

Ho : Akhlak siswa kepada teman tidak lebih dari $60 \%$

c. Ada pengaruh yang signifikan kecerdasan emosional siswa terhadap akhlak siswa kepada teman

Ha : ada pengaruh yang signifikan kecerdasan emosional siswa terhadap akhlak siswa kepada teman

Ho : tidak ada pengaruh kecerdasan emosional siswa terhadap akhlak siswa kepada teman

\section{Metode Penelitian}

Pendekatan dan metode penelitian yang akan penulis gunakan adalah studi korelasional (correlational study) dimana dalam penelitian ini peneliti ingin mendapatkan fakta terperinci tentang bagaimana pengaruh kecerdasan emosional siswa terhadap akhlak siswa kepada teman di kelas VIII E MTs. MAI Purwakarta.

Penelitian korelasi dengan pengumpulan data untuk menentukan ada tidaknya hubungan antara dua variabel. Studi korelasional ditujukan untuk meneliti sejauh mana variabel pada satu faktor berkaitan dengan variabel pada faktor lainnya. Temuan yang dihasilkan pada penelitian korelasional dapat berupa kualifikasi sebagai berikut:

Korelasi positif, yaitu korelasi dari dua variabel atau lebih, dimana jika nilai variabel yang satu meningkat maka variabel yang lain pun akan meningkat dan begitu juga sebaliknya.

a. Korelasi negatif, yaitu korelsi dari dua variabel atau lebih, dimana jika nilai variabel yang satu meningkat maka variabel yang lain pun akan menurun dan sebaliknya.

b. Tidak ada korelasi, yaitu kedua variabel atau lebih tidak menunjukan adanya hubungan.

c. Korelasi sempurna, yaitu kedua variabel atau lebih dimana kenaikan dan penurunan variabel yang satu berbanding dengan variabel lainnya.

Populasi dari penelitian ini adalah siswa kelas VIII.E sebanyak 46 siswa yang terdiri dari 18 siswa laki-laki dan 28 siswa perempuan. Sampel dalam penelitian ini adalah semua siswa sejumlah 46 orang. Sampel ini diambil karena sampel bersifat homogen. Dalam penelitian ini penulis menggunakan penelitian kuantitatif, karena data yang diperoleh nantinya berupa angka. Dari angka yang diperoleh akan dianalisis lebih lanjut dalam analisis data. Penelitian ini terdiri atas dua variabel, yaitu Non Performing Financing (NPF) sebagai variabel bebas (independent) dan Return On Asset (ROA) 
sebagai variabel terikat (dependent). Data kuantitatif yang dibutuhkan pada penelitian ini adalah sebagai berikut:

a. Data kecerdasan emosional siswa kelas VIII. E MTs. MAI Purwakarta

b. Data akhlak siswa kepada teman kelas VIII. E MTs. MAI Purwakarta

Dalam penelitian ini data primernya adalah data terkait variabel $\mathrm{x}$ yakni data tentang kecerdasan emosional siswa dan data terkait variabel y yakni tentang akhlak siswa kepada teman dan bersumber dari siswa. Selain data primer, sumber data yang dipakai peneliti adalah sumber data sekunder, data sekunder didapat melalui berbagai sumber yaitu literatur artikel, serta situs di internet yang berkenaan dengan penelitian yang dilakukan.

Teknik pengumpulan data yang dilakukan dalam penelitian ini adalah dengan menggunakan instrumen. Instrumen digunakan untuk mendapatkan data dan fakta terperinci yang dibutuhkan mengenai kecerdasan emosional siswa dan akhlak siswa kepada teman kelas VIII E MTs. MAI Purwakarta Tahun Pelajaran 2014/2015. Pengumpulan data dilakukan dengan menggunakan metode angket dan wawancara.

Analisis data yang diperoleh dari hasil penelitian dikumpulkan ke dalam data kualitatif dan kuantitatif. Data kualitatif dianalisis dengan logika sedangkan data kuantitatif dilakukan dengan analisis statistika. Adapun variabel-variabel tersebut adalah; kecerdasan emosional siswa (variabel x), akhlak siswa kepada teman (variabel y).

Sebelum mendeskripsikan data, terlebih dahulu peneliti melakukan pengukuran dengan sebelumnya mengumpulkan data menggunakan kuesioner yang terdiri dari pertanyaan-pertanyaan yang masing-masing pertanyaan disertai lima pilihan jawaban. Dari kelima alternatif jawaban yang harus dipilih oleh responden kemudian disusun kriteria penilaian sebagai berikut:

1) Nilai komulatif adalah nilai dari setiap item pertanyaan yang merupakan jawaban dari 46 responden.

2) Persentase adalah nilai komulatif item dibagi dengan nilai frekuensinya dikalikan dengan $100 \%$.

Jumlah responden 46 orang dan nilai skala pengukuran terbesar adalah 5 . Sedangkan skala pengukuran terkecil adalah 1. Maka nilai komulatif terbesar adalah 46 x $5=230$ dan jumlah nilai komulatif terkecil adalah $46 \times 1=46$. Adapun nilai persentase terbesar adalah $(230 / 230) \times 100 \%=100 \%$ dan nilai persentase terkecil adalah (46 / 230) $\times 100 \%=20 \%$. Dari persentase tertinggi dan terendah tersebut dapat diperoleh nilai rentang $100 \%-20 \%=80 \%$. Dan jika nilai rentang tersebut dibagi dengan 5 skala pengukuran ( $80 \%$ dibagi 5), maka didapat nilai interval persentase sebesar $16 \%$.

Uji normalitas data bertujuan untuk mengetahui apakah data yang diperoleh dari hasil penelitian berdistribusi normal atau tidak. Hal ini dilakukan untuk memudahkan perhitungan dan analisis data yang diperoleh dari lapangan. Uji linieritas dengan menggunakan aplikasi SPSS. Analisis korelasi merupakan analisis hubungan dua variabel atau lebih, yaitu antara variabel bebas dengan variabel terikat. Hubungan korelasi terdiri 
atas dua jenis, yakni Bivariate Correlation dan Multivariate Correlation. Bovariate Correlation yaitu analisis terhadap hubungan antara dua variabel, satu variabel bebas dengan satu variabel terikat. Multivariate Correlation yaitu analisis hubungan antara lebih dua variabel bebas dengan satu variabel terikat. Regresi adalah bentuk hubungan fungsional antara variabel-variabel. Sedangkan analisis regresi adalah mempelajari bagaimana antar variabel saling berhubungan.

\section{Analalisis dan Pembahasan Temuan Penelitian}

\section{Deskripsi Hasil Penelitian}

Penelitian ini dilakukan di MTs. MAI yang berlokasi di Purwakarta, Jawa Barat. Subyek penelitian adalah siswa kelas VIII E tahun pelajaran 2015/2016 sebanyak 48 siswa.

\section{a. Kecerdasan Emosional Siswa}

Jumlah responden 46 orang dan nilai skala pengukuran terbesar adalah 5 . Sedangkan skala pengukuran terkecil adalah 1. Maka nilai komulatif terbesar adalah 46 x $5=230$ dan jumlah nilai komulatif terkecil adalah $46 \times 1=46$. Adapun nilai persentase terbesar adalah $(230 / 230) \times 100 \%=100 \%$ dan nilai persentase terkecil adalah $(46 / 230) \times 100 \%=20 \%$. Dari persentase tertinggi dan terendah tersebut dapat diperoleh nilai rentang $100 \%-20 \%=80 \%$. Dan jika nilai rentang tersebut dibagi dengan 5 skala pengukuran (80\% dibagi 5), maka didapat nilai interval persentase sebesar $16 \%$.

Berdasarkan data yang diperoleh, skor hitungnya adalah 5428 (skor kriterium 7130). Dengan demikian nilai Kecerdasan Emosional Siswa adalah 5428 / 7130 x $100 \%=76,13 \%$ (dengan kategori baik). Jika dibuat dalam skala 10, maka nilai Kecerdasan Emosional Siswa adalah 0,76. Nilai mean untuk kecerdasan emosional siswa menunjukan nilai 118,00 median 117,00 dan mode 106. Sedangkan nilai standar deviasi untuk kecerdasan emosional siswa menunjukan nilai 6,186 varians 38,267 dan range 22 .

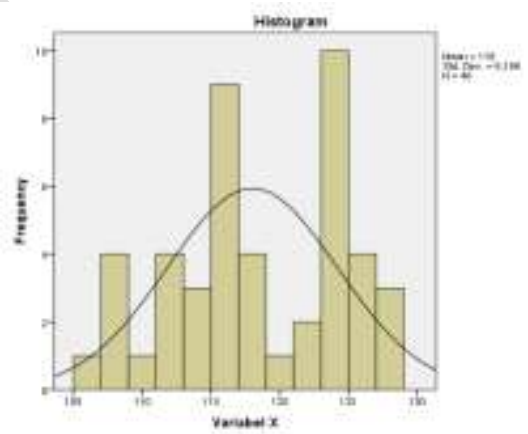

Gambar di atas menunjukan histogram memiliki bentuk normal (simetris/bentuk lonceng), rata-rata histogram terletak di tengah range data.

\section{b. Akhlak Siswa kepada Teman}

Berdasarkan data yang diperoleh, skor hitungnya adalah 6077 (skor kriterium 8050). Dengan demikian nilai Kecerdasan Emosional Siswa adalah 6077 / 8050 x 
$100 \%=75,49 \%$ (dengan kategori baik). Jika dibuat dalam skala 10, maka nilai Kecerdasan Emosional Siswa adalah 0,75.

Nilai mean untuk akhlak siswa kepada teman menunjukan nilai 132,11 median 131,00 dan mode 130. Sedangkan nilai standar deviasi untuk akhlak siswa kepada teman menunjukan nilai 5,322 varians 28,321 dan range 29.

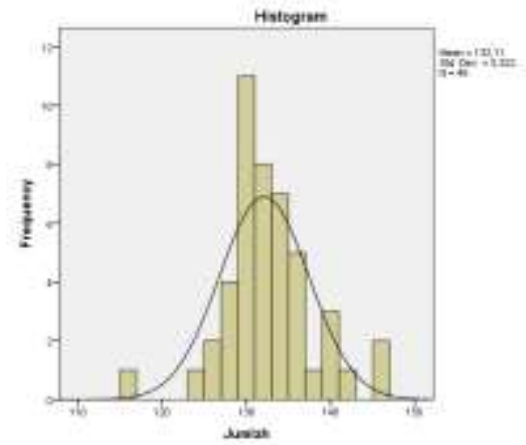

Gambar di atas menunjukan histogram memiliki bentuk normal (simetris/bentuk lonceng), rata-rata histogram terletak di tengah range data.

\section{Uji Prasyarat Analisis}

\section{a. Uji Normalitas}

Berdasarkan hasil uji One-Sample Kolmogorov-Smirnov Test diketahui bahwa nilai signifikansi variabel $X$ (Kecerdasan Emosional Siswa) sebesar 0,005 dan nilai signifikansi variabel Y (Akhlak Siswa kepada Teman) sebesar 0,065 lebih besar dari 0,05 sehingga dapat disimpulkan bahwa data yang peneliti uji berdistribusi normal.

\section{b. Uji Linearitas}

Berdasarkan nilai signifikansi, diperoleh nilai signifikansi 0,131 lebih besar dari 0,05 sehingga terdapat hubungan linear secara signifikan antara variabel $\mathrm{X}$ (Kecerdasan Emosional Siswa) dengan variabel Y (Akhlak Siswa kepada Teman).

Berdasarkan nilai $\mathrm{F}$ dari data di atas, diperoleh nilai $\mathrm{F}_{\text {hitung }}=1,610$, sedangkan $\mathrm{F}$ tabel $=1,66$. Karena nilai $\mathrm{F}$ hitung lebih kecil dari nilai $\mathrm{F}$ tabel, maka dapat disimpulkan bahwa terdapat hubungan yang liear secara signifikan antara variabel X (Kecerdasan Emosional Siswa) terhadap variabel Y (Akhlak Siswa kepada Teman).

\section{Pengujian Hipotesis}

\section{a. Uji Hipotesis Variabel X}

Berdasarkan pengujian hipotesis penelitian terhadap variabel X (Kecerdasan Emosional Siswa), yakni dalam uji hipotesis pertama yang diajukan menunjukan lebih dari $60 \%$ dengan kategori cukup, dengan Ho; kecerdasan emosional siswa tidak lebih dari 60\% dan Ha; Kecerdasan emosional siswa lebih dari 60\%. Dari hasil uji hipotesis pertama tersebut didapatkan rata-rata 175,10 dengan jumlah total 5428 dari skor hitung secara keseluruhan. Namun dalam skor ideal 
berdasarkan jumlah data angket dan responden menunjukan jumlah total 7130 dan rata-rata 230. Dari data keseluruhan tersebut didapatkan nilai dari variabel $X$ dengan prosentase $76,13 \%$.

Dari hasil uji hipotesis di atas ternyata ditemukan derajat kesalahan sebesar $5 \%$ dengan $\mathrm{t}_{\text {hitung }}=27,410$ dan $\mathrm{t}_{\text {tabel }}=1,680$. Hal ini menunjukan bahwa $\mathrm{t}$ hitung lebih besar dari t tabel, maka Ho ditolak dan Ha diterima. Kecerdasan emosional siswa lebih dari $60 \%$ dengan kategori cukup. Jadi, hipotesis yang menyatakan bahwa Kecerdasan emosional siswa lebih dari 60\%, dengan kategori cukup diterima. Dari perhitungan ditemukan rata-rata 76,13\%.

\section{b. Uji Hipotesis Variabel Y}

Berdasarkan pengujian hipotesis penelitian terhadap variabel y (Akhlak Siswa kepada Teman), yakni dalam uji hipotesis kedua yang diajukan menunjukan lebih dari $60 \%$ dengan kategori cukup, dengan Ho; akhlak siswa kepada teman kurang dari $60 \%$ dan Ha; akhlak siswa kepada teman lebih dari 60\%. Dari hasil uji hipotesis kedua tersebut didapatkan rata-rata 173,63 dengan jumlah total 6077 dari skor hitung secara keseluruhan. Namun dalam skor ideal berdasarkan jumlah data angket dan responden menunjukan jumlah total 8050 dan rata-rata 230. Dari data keseluruhan tersebut didapatkan nilai dari variabel y dengan prosentase $75,49 \%$.

Dari hasil uji hipotesis di atas ternyata ditemukan derajat kesalahan sebesar $5 \%$ dengan $\mathrm{t}_{\text {hitung }}=17,416$ dan $\mathrm{t}_{\text {tabel }}=1,680$. Hal ini menunjukan bahwa $\mathrm{t}$ hitung lebih besar dari $\mathrm{t}$ tabel, maka Ho ditolak dan Ha diterima. Akhlak siswa kepada teman lebih dari $60 \%$ dengan kategori cukup. Jadi, hipotesis yang menyatakan bahwa Akhlak siswa kepada teman lebih dari 60\%, dengan kategori cukup diterima. Dari perhitungan ditemukan rata-rata 75,49\%.

\section{c. Koefesien Korelasi}

Analisis korelasi menggunakan analisis Pearson Correlation. Hal tersebut dikarenakan variable berdistribusi normal sehingga analisis korelasi menggunakan analisis parametrik. Hasil analisis korelasi dengan menggunakan Pearson Correlation memaparkan nilai koefesien korelasi sebesar 0,615. Nilai $p$ value $<a=0,000<0,05$ sehingga Ha diterima dan Ho ditolak. Jadi kesimpulannya adalah ada pengaruh yang signifikan antara kecerdasan emosional siswa terhadap akhlak siswa kepada teman.

\section{d. Uji Signifikansi}

Uji signifikansi dilakukan untuk menguji sejauh mana hubungan antara variabel X (Kecerdasan Emosional Siswa) dan variabel Y (Akhlak Siswa kepada Teman) signifikan atau tidak. Dari hasil perhitungan diketahui nilai $\mathrm{F}$ hitung adalah 26,758, sedangkan nilai $\mathrm{F}$ tabel adalah 1,65. $\mathrm{F}_{\text {hitung }}>\mathrm{F}$ tabel $=26,758>1,65$. Sehingga hubungan variabel $\mathrm{X}$ signifikan terhadap variabel $\mathrm{Y}$. 


\section{e. Koefesien Determinasi}

Uji kecenderungan dilakukan untuk mendeskripsikan keadaan yang berkembang di lapangan yang dilihat berdasarkan item dalam angket penelitian. Besarnya nilai korelasi variabel $\mathrm{X}$ terhadap variabel $\mathrm{Y}$ adalah 0,615 sedangkan determinasinya sebesar 0,378 sehingga bisa dikatakan variabel $\mathrm{Y}$ dipengaruhi oleh variabel $\mathrm{X}$ sebesar $37,8 \%$.

Nilai $R$ yang merupakan simbol dari nilai koefisien korelasi. Pada tabel di atas nilai korelasinya adalah 0,615 . Hal ini dapat diinterpretasikan bahwa hubungan kedua variabel pada penelitian berada pada kategori kuat.

Berdasarkan hasil perhitungan diperoleh nilai $R$ square atau Coefisien Determinasi yang menunjukan seberapa bagus model regresi yang dibentuk oleh interaksi variabel bebas dan variabel terikat. Nilai yang diperoleh adalah $37,8 \%$ yang dapat ditafsirkan bahwa variabel X (Kecerdasan Emosional Siswa) memiliki pengaruh kontribusi sebesar 37,8\% terhadap variabel Y (Akhlak Siswa kepada Teman) dan 62,2\% dipengaruhi oleh faktor lain di luar variabel $\mathrm{X}$.

\section{f. Persamaan Regresi}

Berdasarkan perbandingan $\mathrm{t}$ hitung dan $\mathrm{t}$ tabel diketahui bahwa $\mathrm{t}$ hitung $=5,173$ sedangkan $t$ tabel dengan taraf signifikansi $5 \%$ dan $\mathrm{df}=\mathrm{N}-2,46-2=44$ maka nilai $\mathrm{t}$ tabel adalah 1,680. Perbandingan antara $\mathrm{t}$ hitung dan $\mathrm{t}$ tabel dapat dikatakan bahwa $\mathrm{t}$ hitung lebih besar dari $\mathrm{t}$ tabel, sehingga Ha diterima dan Ho ditolak.

Berdasarkan hasil perhitungan nilai Constans adalah 69,682, sedangkan nilai kecerdasan emosional siswa adalah 0,529 sehingga persamaan regresinya dapat ditulis $\mathrm{Y}=\mathrm{a}+\mathrm{bX}$ atau $69,628+0,529$. Artinya perubahan pada variabel $\mathrm{X}$ akan diikuti oleh perubahan pada variabel Y secara positif. Koefisien bernilai positif artinya semakin besar kecerdasan emosional siswa mempengaruhi maka akan semakin besar pula perubahan akhlak siswa kepada teman.

\section{Analisis Data (Pembahasan)}

Berdasarkan hasil perhitungan di atas, hasil variabel X (Kecerdasan Emosional Siswa) diperoleh 76,13\% termasuk kategori baik. Sementara hasil variabel Y (Aklak kepada Teman) diperoleh 75,49\% dan termasuk kategori baik.

Sedangkan hasil rumusan hipotesis ketiga yang diajukan "terdapat pengaruh yang signifikan kecerdasan emosional siswa terhadap akhlak siswa kepada teman" telah terbukti dengan persentase sebesar 37,80\% sedangkan sisanya 62,20\% dipengaruhi oleh variabel lainnya di luar variabel kecerdasan emosional siswa yang tidak diteliti dalam penelitian ini.

Adanya hubungan antara dua variabel dalam penelitian ini menunjukan bahwa kecerdasan emosional siswa dengan akhlak siswa kepada teman jelas terbukti pada kasus yang terjadi di kelas VIII E MTs. MAI Purwakarta. Hal ini menandakan bahwa akhlak siswa kepada teman dipengaruhi oleh kecerdasan emosional siswa. Semakin 
baik kecerdasan emosional siswa maka akan berdampak positif dan semakin baik akhlak siswa kepada teman.

Dari hasil penelitian ini dapat dikatakan bahwa kecerdasan emosional siswa telah terbukti berpengaruh terhadap akhlak siswa kepada teman dalam kehidupan seharihari di kelas VIII E MTs. MAI Purwakarta dengan pengaruh sebesar 37,80\%. Kategori pengaruh variabel $\mathrm{X}$ terhadap variabel $\mathrm{Y}$ rendah dengan model regresi linier dan signifikan. Hal ini membuktikan bahwa sisanya dipengaruhi oleh faktor lain di luar variabel yang diteliti.

\section{E. Simpulan}

Kesimpulan diambil dari jawaban-jawaban masalah penelitian, berdasarkan data yang diperoleh dalam penelitian yang berjudul Pengaruh Kecerdasan Emosional Siswa terhadap Akhlak Siswa kepada Teman di Kelas VIII E MTs MAI Purwakarta Tahun Pelajaran 2014/2015 bahwa:

a. Realitas dari kecerdasan emosional siswa di kelas VIII E MTs MAI Purwakarta Tahun Pelajaran 2014/2015 dinilai baik dengan perolehan nilai rata-rata 76,13\%. Nilai rata-rata ini diperoleh berdasarkan pada indikator-indikator dari kecerdasan emosional siswa.

b. Ralitas dari akhlak siswa kepada teman di kelas VIII E MTs MAI Purwakarta Tahun Pelajaran 2014/2015 dinilai baik dengan perolehan nilai rata-rata 75,49\%. Nilai ratarata ini diperoleh berdasarkan pada indikator-indikator dari akhlak siswa kepada teman.

c. Realitas dari pengaruh kecerdasan emosional siswa berpengaruh terhadap akhlak siswa kepada teman di kelas VIII E MTs MAI Purwakarta Tahun Pelajaran 2015/2016, meskipun nilai pengaruhnya hanya 37,80\% dan memiliki nilai korelasi 0,615 yang dapat dikategorikan bahwa pengaruh antara kedua variabel kuat. Sehingga dapat diperoleh keputusan bahwa Ho ditolak dan Ha diterima. Maka kecerdasan emosional siswa perpengaruh secara nyata dan positif terhadap akhlak siswa kepada teman, dan sisanya $62,20 \%$ dipengaruhi oleh variabel lain di luar penelitian. 


\section{Daftar Pustaka}

Arikunto, Suharsimi. 2005. Prosedur Penelitian: Suatu Pendekatan Praktek. Jakarta: Rineka Cipta

Az-Zarnuji, Syekh. 2009. Panduan Akhlak Guru dan Murid; Terjemahan dari Kitab At-Ta'lim al-Muta'alim. Demak: Pustaka Ilmu

Depdiknas, 2008. Kamus Besar Bahasa Indonesia. Jakarta: Gramedia Pustaka Indonesia

Djatnika, Rahmat. 1996. Akhlak Mulia. Jakarta: Pustaka

Golman, Daniel. 2002. Emitional Intelligence (Terjemahan). Jakata: Gramedia Pustaka Utama

Manpan Drajat, M. R. E. (2015). Etika Ptrofesi Guru. Alfabeta.

Effendi, M. Ridwan dan Manpan Drajat. Etika Profesi Guru. Cet. I: Bandung; Alfabeta, 2014.

Effendi, M. R., \& Nurpratiwi, S. (2021). H Hubungan Keberagamaan dan Perilaku Altruistik Mahasiswa. al-Afkar, Journal For Islamic Studies, 4(1).

Nurpratiwi, M. R. E. dan S. (2021). Hubungan Keberagamaan dan Perilaku Altruistik Mahasiswa. Al-Afkar, 4(1), 83-97.

https://doi.org/https://doi.org/10.31943/afkarjournal.v4i1.181

Pamungkas, M. Imam. 2012. Akhlak Muslim Modern. Bandung Marja

Ramayulis. 2010. Ilmu Pendidikan Islam. Jakarta: Kalam Mulia

Saebani, Beni Ahmad. 2010. Ilmu Akhlak. Bandung: Pustaka Setia

Suharsono. 2005. Melejitkan IQ, EQ, SQ. (Depok: Inisiasi Press

Syah, Darwyan. 2009. Pengantar Statistik Pendidikan. Jakarta: Gaung Persada

Press 